\title{
Cerebrospinal fluid immunoglobulins and complement in meningococcal meningitis
}

\author{
H. C. WHitTLE AND B. M. GREENWOOD
}

From the Department of Medicine and Paediatrics, Ahmadu Bello University Hospital, Zaria, Nigeria

SUMMARY Cerebrospinal fluid (CSF) immunoglobulins (IgA, IgG, IgM) were measured in 107 patients with meningococcal meningitis. Levels were correlated significantly with CSF total protein, and both CSF immunoglobulin and protein increased with age. $\mathrm{C}_{3}$ was measured in the CSF of 38 patients and was also closely correlated with the CSF protein level. $\mathrm{C}_{3}$ breakdown products were found in all of six CSFs tested. The CSF immunoglobulin and complement were thought to have leaked from the plasma due to inflammation of the meninges and had little value in diagnosis or prognosis.

There has been some interest in measuring cerebrospinal fluid (CSF) immunoglobulin and complement levels in meningitis in the hope that this might aid diagnosis and prognosis. O'Toole et al. (1971) found CSF IgA and IgG to be correlated with CSF protein in pneumococcal, meningococcal, and tuberculous meningitis. In contrast, there was no correlation between CSF IgM and protein in pneumococcal meningitis, suggesting that it might have been synthesised within the central nervous system. Buchanan and MacNab (1972) found it impossible to distinguish between the various types of pyogenic meningitis on the basis of CSF immunoglobulin pattern but showed that in encephalitis CSF complement was absent and the immunoglobulins normal. Smith et al. (1973) found a rise in CSF IgM concentration in the acute phase of purulent meningitis but not in viral meningitis. They suggested that this might be of diagnostic value.

In this study we have measured CSF immunoglobulin and complement concentration in patients with meningococcal meningitis in an attempt to assess their origin and to determine whether CSF immunoglobulin levels are of prognostic value in this infection,

\section{Material and methods}

CSF was obtained from 107 patients with group A meningococcal meningitis and 22 patients with group $\mathrm{C}$ meningococcal meningitis. In 112, the

Received for publication 19 January 1977 diagnosis was made by finding meningococcal antigen and/or a positive bacterial culture in the CSF; in 17, the diagnosis was based on an increase in haemagglutinating antibody in the serum (Greenwood and Whittle, 1974).

Immunoglobulins and complement were measured by the Mancini technique using monospecific antisera (Hyland Laboratories). Immunoglobulin levels are expressed in international units and $C_{3}$ levels as a percentage of a pooled adult Nigerian serum standard. Edetic acid CSF samples were tested for $\mathrm{C}_{3}$ breakdown products by crossover immunoelectrophoresis (Greenwood and Whittle, 1976). CSF protein was measured by a turbidometric method (Varley, 1969).

\section{Results}

CSF IMMUNOGLOBULINS

Table 1 shows the mean CSF immunoglobulin and protein levels according to age. All three classes of immunoglobulins rose with age as did the total CSF

Table 1 Mean CSF immunoglobulin and protein levels according to age

\begin{tabular}{|c|c|c|c|c|c|}
\hline \multirow{2}{*}{$\begin{array}{l}\text { Age } \\
\text { (years) }\end{array}$} & \multirow[t]{2}{*}{ No. } & \multicolumn{3}{|c|}{ Immunoglobulins $(\mathrm{iu} / \mathrm{ml})$} & \multirow{2}{*}{$\begin{array}{l}\text { Protein } \\
(\mathrm{g} / l)\end{array}$} \\
\hline & & $A$ & $G$ & $M$ & \\
\hline $\begin{array}{r}0-4 \\
5-14 \\
15-44\end{array}$ & $\begin{array}{l}22 \\
60 \\
25\end{array}$ & $\begin{array}{l}1 \cdot 1 \pm 0 \cdot 8 \\
3 \cdot 7 \pm 3 \cdot 6 \\
7 \cdot 9 \pm 7 \cdot 8\end{array}$ & $\begin{array}{r}1.9 \pm 2.8 \\
7 \cdot 7 \pm 6.9 \\
13.9 \pm 11.3\end{array}$ & $\begin{array}{r}3 \cdot 2 \pm 2 \cdot 7 \\
7 \cdot 2 \pm 6 \cdot 6 \\
12 \cdot 2 \pm 12 \cdot 3\end{array}$ & $\begin{array}{l}203 \pm 137 \\
287 \pm 170 \\
368 \pm 220\end{array}$ \\
\hline
\end{tabular}

Differences significant at $5 \%$ level or less except for protein between 5-14 and 15-44 age groups 
protein content. CSF immunoglobulin levels were found to be significantly correlated with protein levels $(r=0.5$ for $\operatorname{IgA}, r=0.6$ for $\operatorname{IgG}, r=0.7$ for IgM ; $\mathrm{P}<0.001$ for all three). No significant correlation was found between serum and CSF immunoglobulin levels. Haemagglutinating antibody was detected in only one of 81 specimens tested.

Patients with severe neurological disease, such as deep coma, fits or upper motor neurone lesions disease, tended to have higher CSF immunoglobulin levels (Table 2) but the differences were not significant and were of no use in prognosis.

Table 2 Mean CSF immunoglobulin levels according to neurological damage

\begin{tabular}{|c|c|c|c|c|}
\hline \multirow[t]{2}{*}{ Damage } & \multirow[t]{2}{*}{ No. } & \multicolumn{3}{|c|}{ Immunoglobulins $(\mathrm{iu} / \mathrm{ml})$} \\
\hline & & $A$ & $G$ & $M$ \\
\hline $\begin{array}{l}\text { Severe } \\
\text { Mild }\end{array}$ & $\begin{array}{l}22 \\
85\end{array}$ & $\begin{array}{l}3 \cdot 3 \pm 2 \cdot 8 \\
4 \cdot 3 \pm 3 \cdot 1\end{array}$ & $\begin{array}{l}8 \cdot 3 \pm 9 \cdot 1 \\
7 \cdot 9 \pm 7 \cdot 1\end{array}$ & $\begin{array}{l}8 \cdot 7 \pm 8 \cdot 4 \\
7 \cdot 2 \pm 7 \cdot 6\end{array}$ \\
\hline
\end{tabular}

Differences not significant

\section{CSF COMPLEMENT}

The mean CSF $\mathrm{C}_{3}$ level of 38 patients was $8.8 \% \pm$ $9.0 \%$. CSF $\mathrm{C}_{3}$ levels were found to be closely correlated to CSF protein levels $(\mathrm{r}=0.8, \mathrm{P}<0.001)$ but not to serum $C_{3}$ levels $(r=0 \cdot 24, P>0 \cdot 1)$. Six samples of CSF, containing high amounts of $\mathrm{C}_{3}$, were tested for complement breakdown products; all were positive.

\section{Discussion}

We think that the CSF immunoglobulin and $C_{3}$ of most patients with meningococcal meningitis has leaked from the plasma because immunoglobulin and complement levels were significantly correlated with total CSF protein. This is in accord with the view that a non-specific increase in permeability of the blood-CSF barrier, such as in meningitis, results in a general rise in protein concentration in which all the plasma proteins participate (Davson, 1967). Our data do not suggest local production of immunoglobulin in meningococcal meningitis, as is thought to occur in pneumococcal meningitis (O'Toole et al., 1971) and in some chronic forms of meningoencephalitis such as sleeping sickness (Greenwood and Whittle, 1973), neurosyphilis (Kabat et al., 1948), and subacute sclerosing panencephalitis (Connolly et al., 1967). Surprisingly, CSF immunoglobulin and $\mathrm{C}_{3}$ levels were not related to serum levels: perhaps a variable proportion of these proteins are degraded in the CSF or fixed to bacterial antigen, so distorting the relationship.
It is interesting that CSF total protein and immunoglobulin increased with age, a finding not previously recorded. Perhaps the inflammatory response is greater in older patients as they have acquired some cross-reacting immunity to the invading meningococcus (Goldschneider et al., 1969). Consequently, younger children who have no immunity may have a poorer prognosis (Whittle et al., 1977) because their inflammatory response is less. Free antibody was detectable in the CSF of only one patient although we have previously shown that about $15 \%$ of patients with meningococcal meningitis have high serum antibody levels to the invading meningococcus on admission (Greenwood and Whittle, 1974). Presumably this antibody forms complexes with antigen on entry to the CSF.

Most of our patients had some complement in the CSF, and in those with high levels, $C_{3}$ breakdown products were found, indicating complement activation. This may have resulted from an antigen antibody reaction between bacteria and antibody leaked from the plasma, by the release of endotoxin and activation of the alternative complement pathway or by the proteolytic activity of bacterial enzymes. Complement bound to bacteria would aid in phagocytosis, and we have evidence that complement activation in the CSF leads to the production of chemotactic factors attracting polymorphs to the CSF (Greenwood, unpublished).

It is unlikely that CSF immunoglobulin or complement levels will be of diagnostic or prognostic value in acute pyogenic meningitis if these proteins are due to a leak of plasma across the CSF/blood barrier-the result of a non-specific meningeal inflammation. We have found these measurements of no value in the diagnosis or management of patients with meningococcal meningitis.

We thank Mr Moses Damisah and Miss Rosalind Vick for skilled technical help. This study was supported by grants from the Medical Research Council, UK.

\section{References}

Buchanan, N. and MacNab, G. S. (1972). Cerebrospinal fluid complement and immunoglobulins in meningitis and encephalitis. South African Medical Journal, 46, 1376-1382.

Connolly. J. H., Allen, I. V., Hurwitz, L. J., and Millar, J. H. D. (1967). Measles-virus antibody and antigen in subacute sclerosing panencephalitis. Lancet, 1, 542-544.

Davson, H. (1967). Physiology of the Cerebrospinal Fluid, p. 289. Churchill, London.

Goldschneider, I., Gotschlich, E. C., and Artenstein, M. S. (1969). Human immunity to the meningococcus. 
2. Development of natural immunity. Journal of Experimental Medicine, 129, 1327-1348.

Greenwood, B. M. and Whittle, H. C. (1973). Cerebrospinal-fluid IgM in patients with sleeping-sickness. Lancet, 2, 525-527.

Greenwood, B. M. and Whittle, H. C. (1974). Antigennetative meningitis due to group A Neisseria meningitidis. Journal of Infectious Diseases, 129, 201-204.

Greenwood, B. M. and Whittle, H. C. (1976). Complement activation in patients with Gambian sleeping sickness. Clinical and Experimental Immunology, 24, 133-138.

Kabat, E. A., Glusman, M., and Knaub, V. (1948). Quantitative estimation of the albumin and gamma globulin in normal and pathologic cerebrospinal fluid by immunochemical methods. American Journal of
Medicine, 4, 653-662.

O'Toole. R. D., Thornton, G. F., Mukherjee, M. K., and Neogy, K. N. (1971). Cerebrospinal fluid immunoglobulins in bacterial meningitis. Archives of Neurology, 25, 218-224.

Smith, H., Bannister, B., and O'Shea, M. J. (1973). Cerebrospinal-fluid immunoglobulins in meningitis. Lancet, 2, 591-593.

Varley, H. (1969). Practical Clinical Biochemistry, 4th edition. Heinemann, London.

Whittle, H. C., Fakunle, Y. M., Abdullahi, M. T., and Parry, E. H. O. (1977). Clinical features of epidemic meningococcal meningitis. Nigerian Medical Journal, (In press.) 